Sustainable Regional Development: Communities and Policy

\section{Facilitating Autonomy}

\section{Nachhaltige Entwicklung ist ohne regionalen Bezugspunkt nicht vorstellbar. Sie kann nur auf der Ebene einer Region, deren Grenzen von der dort lebenden Bevölkerung definiert werden, in Gang gesetzł werden. Wie kann dies gesche- hen und welche Rolle spielt dabei die Regierung? Im Kern geht es darum, das soziale Kapital der Region zu stärken und einen eigenständigen Entwicklungs- prozeß zu ermöglichen. Die Grundlage dafür bilden gemeinsame Wertvorstel- lungen und Entrepreneurship vor Ort.}

W Von Gerry Sweeney hy is sustainable regional development the major issue facing society? There are several factors at play. The innovations and the new entrepreneurial firms which create economic prosperity are 'regional'. Economic development happens in specific places and spreads to other places as innovations are diffused and further innovation and wider prosperity are created elsewhere. The term 'regional' is a somewhat loose one. Dynamic places vary considerably in size, population and physical environment; they are generally relatively small localities whose boundaries are social and natural rather than administrative. They are characterised by the intangibles of culture, social behaviour and values and the attachment of people to their place. Sustainable development is a mode of development based on making and doing things in new ways and therefore one even more dependent on the innovative and entrepreneurial dynamism of specific places and on the diffusion of their innovations to other places.

The environment is also 'regional'. Nature makes no two things the same. The visible landscape and the eco-systems embedded within it change from place to place and each 'regional' environment contributes to the quality of the national or global environment, just as a national economy is the sum, the pluses and minuses, of its 'regional' economies. Pollution or waste created in one place, like an innovation which is the source of increased prosperity, is diffused to other places. The ways in which a community in pursuit of its own economic prosperity and leisure interacts with its own and others' environments is an outcome of its culture and value systems. The environment is socially constituted. What is the environment changes from place to place and group to group as the value system changes. Hence the mode in which an environment is exploited endogenously or exogenously is determined by the value system of the exploiters, natives or outsiders.

Economic prosperity is also dependent on people whose community has a particular culture and value system. It is created by people who set up new firms and thereby bring their innovative products and services to society and the market. Without the new firm or organisation and therefore without the entrepreneur, there is no innovation. Furthermore, innovation is not restricted to technology. Roughly fifty per cent of innovative products are design based and there is the further phenomenon that increasingly there are innovative in the provision of social services them are the product of 'regional' cultures, which are distinctive - different ways of thinking, communicating and interpreting information. Because they are different, such communities are creative, rather than conforming to a standardised homogenous national or global culture. They innovate.

Where a community is entrepreneurially dynamic, its culture is one of taking control of one's own destiny. People therefore have a propensity to set up their own economic activities. Perhaps paradoxically, the value system of the community is one which is also imbued by commitment to the res publica, the well being of other members of the community and of the community itself. There is a sharing and mutual support between entrepreneurs and between each section of the community. There is consensus as to objectives and control of opportunistic behaviour. The economic prosperity is diffused through society. The economic organisational structure is a devolved new types of organisation emerging which are new social entrepreneurs doing things in new ways. Entrepreneurs and those who support horizontal one, populations of small firms closely interconnected and large firms embedded in the networks of small firms, a structure matched by the autonomy of decision making in the public and private infrastructure.

The value system and structure are in contrast to the Neo-Fordist structures and ethos which are tending to dominate Western and now Central and Eastern European economies. Neo-Fordism is centralist, exploitative of factors of production and non-integrated in 'regional' economies and tends to create wealth for a managerial elite. Both Fordism and Neo-Fordism are oriented to mass-consumerism and are non-sustainable. Fordism whilst raising standards of living had significant environmental and social costs and Neo-Fordism is tending to suppress innovative and entrepreneurial vitality, to homogenise culture and relatively to depress standards of living other than those of the elite.

Inevitably therefore sustainable development is something which is intrinsically 'regional', it can be created only at a 'regional' level, a space whose boundaries are defined by the community which lives within it. How can it happen and what is the role of government? (1)

\section{Developing Social Capital}

The function of policies and actions by government at all levels is to enable the social capital of each locality or 'region' to become dynamic in generating endogenously their economic, sociocultural and environmental development in a sustainable manner.

The social capital of dynamic localities has four major components:

\section{- social cohesion}

the intensive social and business interrelationships based on the shared value system of a community, leading to sharing, collaboration and consensus, the basis of participative democracy and of orienting action to the res publica, the welfare of all sections of the community.

\section{- entrepreneurial potential:}

the propensity to take control of one's own destiny by founding a new economic activity within the context of supporting the welfare of one's community and also, as the project case studies revealed, to found a social activity to address needs of the community or sections of the community.

\section{skills:}

the skills in making and doing things obtained by a majority of young people from a vocational training system continued through the third 
level, and containing tacit skills and know how, the subtle understanding of technology, social interaction and eco-systems.

\section{autonomy of decision making:}

autonomy of strategic decision making in all public and private sectors.

In the last four decades, dynamic localities have mobilised their social capital to enter a process of self-governance, to create new forms of economic organisation with high learning and to diffuse prosperity and social progress through all sectors of their communities. This phenomenon of self-governance is growing in Europe. The phenomenon is marked by a willingness of some central and regional governments to collaborate and support such initiatives, many of which carry out what would formerly have been considered to be public functions. Sustainability in economic, social and environmental terms is being assured through constant and shared learning, commitment to the public good rather than a narrow individualist private gain, and a consensual vision of the future.

Government policy in essence should have two functions, one to support the development of the social capital, and the second to support and collaborate with new self-governing organisations which mobilise the social capital of a 'region'.

\section{- Far Reaching Concept}

The major principle on which policy and administrative structures should be based is clearly that of subsidiarity. Decisions should be taken at the lowest level possible with setting of qualitative standards of performance at a higher level to ensure accountability. No policy or measure should be prescriptive. Innovation of its essence is an unanticipated event. The appropriateness of a prescriptive measure in one social, economic, cultural or environmental framework may be entirely inappropriate in another. In fact, recognising that exogenous determination or intervention has generally some negative impact however well intentioned, policies should be facilitating. They should facilitate the emergence of unanticipated developments, a variety of development approaches, the customisation to local needs, culture, structures etc.

This concept of facilitation is far reaching. On the one hand it should allow the evolution of an own mode of self-governance for each action within each community. This entails that there should be mutual respect for the autonomy of partners and acceptance of negotiated responsibilities. Where there is social cohesion and therefore intensive social interaction and trust between individuals and groups and sectors, there is constant listening and learning and moderation of views as to the needs of each and the actions to be undertaken. Where a local government and the agencies of central government are embedded in these interactions and share the value system, each acts for the public good, the res publica.

Communities with good social cohesion have an attachment to place and pride in place, and therefore building in an environmental dimension and a concern for environmental sustainability into the value system is relatively easy. Pride in place is enhanced. Where social cohesion has disintegrated or is disintegrating, it is difficult to enter on a process of endogenously directed economic, socio-cultural and environmental sustainability. Patience and time are needed to build consensus and a vision of the future but only the community itself can do this, however much it may be facilitated by external actors. Policy programmes which provide support for specific periods and lack continuity inevitably have negative effects resulting in capture for their own ends by national or local elites, visible for example in fund chasing.

'Regions' or localities are diverse in every respect of economy, society, culture and environment and the evidence of research illustrates that only when a community enters on a process of self-governance appropriate to itself does it begin to enter on a process of sustainable development. Intrinsic to this process are the commitment to the res publica of hte community itself as the core of community and to facilitating the mobilisation of a community's social capital through self governance in partnership with, and support of, each level of government.

\section{Anmerkung}

(1) The article draws on work carried out within the IN.SU.RE.D project (Instruments for Sustainable Regional Development) coordinated by EURES, Basler Straße 19, 79100 Freiburg, from whom reports are obtainable, and carried out with support from the EU DG XII Climate and Environment Programme.

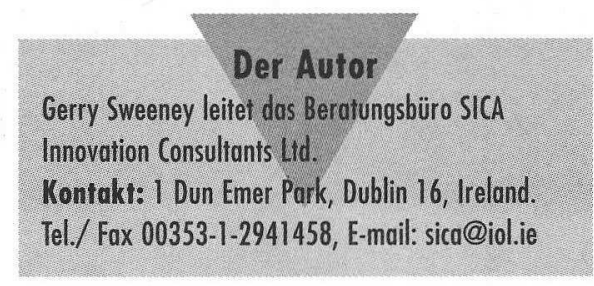

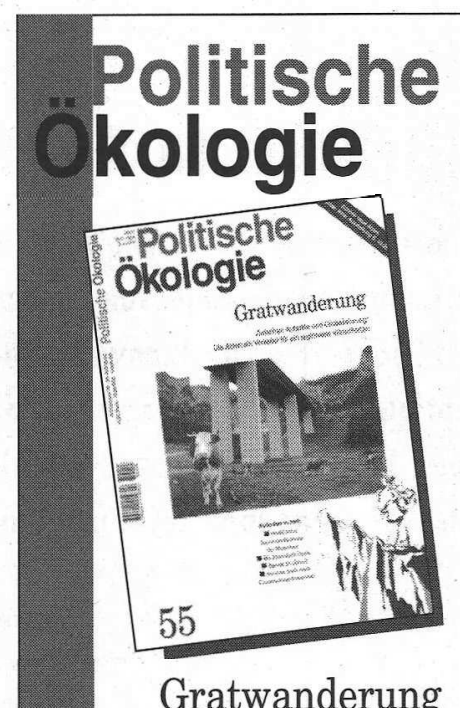

Zwischen Autarkie und Globalisierung: Die Alpen als Vorreiter für regionales Wirtschaften Ausgabe Nr. 55 บं ber Nachhaltiges WirtschafGrundsätzliches diskutiert. Konzepte und Absichtserklärungen liegen vor, aber nur wenige konkrete und überzeugende Beispiele. Wäre da nicht eine Region, in der früher und zahlreicher als andernorts eine Vielfalt von Initiativen entstanden ist: die Alpen.

Unser durch Skibrille oder Sonnengläser getrübter Blick hat diese Region lange in eine touristische Sonderrolle gedrängt. Dabei stehen die Alpen - wenn auch zum Teil verschärft und damit sichtbarer - vor denselben Problemen und Herausforderungen wie andere Regionen in $\mathrm{Eu}$ ropa und Deutschland. Und sie besitzen einen Erfahrungsschatz, den zu bergen sich für viele außeralpine Initiativen mehr als lohnen würde. Begeben Sie sich auf die Schatzsuche.

w. Bätzing: Wirtschaftsverflechtungen im Alpenraum - W. Fink: Verkehrskonzept Kleinwalsertal • S. Lanner: Telekommunikation als Hoffnung $-\mathrm{K}$. Lindner: Hindelang - eine Beispielgemeinde? • P. Donatsch: Ökomarkt Graubünden • K. Amor: Gemeinde-Netzwerk ,Alliance in den Alpen“ • A. Weissen: Länderübergreifende Alpenkonvention $\bullet D$. Siegrist: Nachhaltige Alpenpolitik • E. Loibl: Erfolgsbedingungen für Initiativen im ländlichen Raum

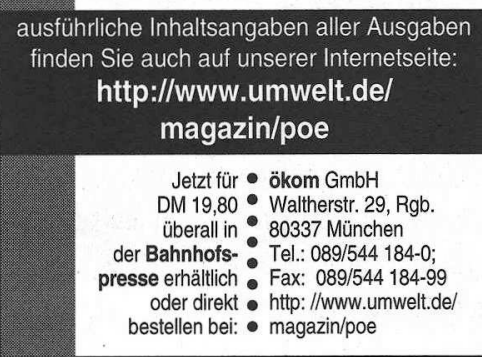




\section{Regionen der Zukunft}

\section{Viele Potentiale einer Nachhaltigen Entwicklung können nicht alleine von ein- zelnen Kommunen erschlossen werden. Der Wettbewerb "Regionen der Zukunft" fördert daher innovative Ansätze einer nachhaltigen Raum- und Sied- lungsentwicklung in den Regionen, die sich mit den Leitlinien „Preise statf Plä- ne" und "Projekt- und Prozeßorientierung" charakterisieren lassen. Die uner- wartete Resonanz läßt auf einen Innovationsschub hoffen.}

$\mathrm{D}$ regionale Agenden für eine nachhaltige Raumund Siedlungsentwicklung" (1) wurde im September 1997 von der Bundesforschungsanstalt für Landeskunde und Raumordnung (2) öffentlich ausgelobt. Während der dreijährigen Laufzeit des Wettbewerbs sollen die Teilnehmer innovative Ansätze einer nachhaltigen Raum- und Siedlungsentwicklung in den Regionen erarbeiten und in ersten Ansätzen bis zum Sommer 2000 umsetzen. „Regionen der Zukunft“ sind ein Baustein der „Modellvorhaben der Raumordnung“ (MORO) des Bundesministeriums für Raumordnung, Bauwesen und Städtebau. Dieses Aktionsprogramm zur Umsetzung des Raumordnungspolitischen Handlungsrahmens aus dem Jahr 1995 dokumentiert auch eine Bedeutungsverschiebung in der Raumordnung: hin zu einer stärkeren Prozeß- und Projektorientierung und einer aktiveren Rolle in der räumlichen Entwicklung. Mit den Modellvorhaben - u.a. Städtenetze, Regionalkonferenzen und transnationale Zusammenarbeit auf dem Gebiet der Raumordnung - sollen laufende regionale Prozesse unterstuitzt und gefördert werden. Ziel dieser umsetzungsorientierten Projekte ist es, Forschung und Praxis so miteinander zu verknüpfen, daß eine rasche Umsetzung von Erkenntnissen in die Praxis gewährleistet ist. Insbesondere geht es um die Entwicklung nachahmenswerter Beispiele, die von der Raumordnung aufgegriffen und sowohl als Impuls als auch als Korrektiv an Akteure in allen Regionen Deutschlands weitergegeben werden können. Außerdem sollen Erkenntnisse für notwendige Veränderungen staatlicher Rahmenbedingungen gewonnen werden.

Üblicherweise werden im Rahmen des MOROProgrammes ausgewählte Modellvorhaben bzw. Modellregionen einzeln betreut, um vorbildhaf- te Ansätze zu entwickeln und anderen Regionen anregende Beispiele zu geben. „Regionen der Zukunft" versucht hingegen, entsprechende Prozesse uiber einen Wettbewerb in Gang zu setzen. So können nicht nur mehr Regionen in das Modellvorhaben mit einbezogen werden, sondern der Wettbewerb ist auch Ansporn für Initiative und Innovation.

In der ersten Stufe dieses Wettbewerbs wurden die Interessenten aufgefordert, erste Entwürfe einer regionalen Agenda vorzulegen. Gefragt wurde nach Konzepten und Projekten, die etwa auf eine verkehrsreduzierende Siedlungsstruktur, eine sparsame Flächeninanspruchnahme und einen besseren Freiraumschutz zielen, effizientere Material- oder Energieflüsse vorsehen oder innovative, umweltorientierte Betriebe fördern. Besondere Bedeutung wurde der Ausgestaltung regionaler Kooperations- und Dialogprozesse beigemessen. Der räumliche Zuschnitt als auch die organisatorische Trägerschaft der angesprochenen Regionen wurden dabei als variabel angesehen. Im Wettbewerb selbst soll sich entscheiden, welche „Regionen“ und welche „Träger" sich als erfolgreich erweisen.

Zur Orientierung waren rahmensetzende und in ihrer Abstraktion weitgehend konsensfähige, gleichwohl in der praktischen Umsetzung längst noch nicht selbstverständliche ökologische, soziale und ökonomische Ziele vom Auslober vorgegeben (vgl. Tabelle 1). Diese Ziele sollten von den Akteuren in den Regionen jeweils situationsgerecht angepaßt und konkretisiert werden. 87 Regionen haben bis Ende Januar dieses Jahres Bewerbungsunterlagen - ihren ersten Entwurf einer regionalen Agenda - eingereicht, um sich für die Teilnahme am Ideen- und Realisierungswettbewerb zu qualifizieren. Ende Mai hat eine unabhängige Wettbewerbsjury davon 26 Regionen ausgewählt (siehe Kasten).

\section{Aufbruchstimmung nutzen}

Die selbst für die Initiatoren dieses Wettbewerbs unerwartet hohe Resonanz, die durch die Auslobung hervorgerufen wurde, deutet auf eine Aufbruchsstimmung in den Regionen hin. Es hat sich eine Atmosphäre entwickelt, in der Kurskorrekturen auf der Ziel- und Handlungsebene wieder verstärkt eine Chance haben.

Nachhaltige Entwicklung - verstanden als Offenhalten von Optionen für die Zukunft - wird nur über längerfristige Anpassungszeiträume erreicht werden können, sie erfordert jedoch heute schon den Einstieg in den notwendigen Strukturwandel. Für den Bereich der räumlichen Planung bedeutet dies, Entscheidungen zu treffen bzw. zu unterstiitzen, deren Auswirkungen die Chancen zukünftiger Generationen auf regional gleichwertige Lebensbedingungen nicht schmälern.

Es wird eine nachhaltige Raumentwicklung angestrebt, die die sozialen und wirtschaftlichen Anspriche an den Raum mit seinen ökologischen Funktionen in Einklang bringt und zu einer dauerhaften, großräumig ausgewogenen Ordnung fuihrt ( $§ 1$ und 2 des neuen Raumordnungsgesetzes). Dafür schafft die räumliche Planung bauliche, räumliche und infrastrukturelle Voraussetzungen. Sie kann eine derartige Entwicklung alleine aber nicht hinreichend steuern.
Tabelle 1: Rahmensetzende Ziele einer nachhaltigen Raum- und Siedlungsentwicklung

\begin{tabular}{|c|c|}
\hline Ökologische Ziele & $\begin{array}{l}\text { - Reduzierung der Freiflächeninonsprurhnohme für Siedlungszwecke } \\
\text { - Förderung lokaler und regionaler Stoffströme und Energieflüsse } \\
\text { - Sparsame Nutzung nichir-regenerierbarer Rohstoffe und Energiequellen } \\
\text { - Reduzierung der Abgabe von Schadstoffen/Emissionen in die Natur }\end{array}$ \\
\hline Sozidele Ziele & $\begin{array}{l}\text { Gleichberechitigte Beteiligung und Beruicksichtigung der Interessen aller regionalen Akteure } \\
\text { und Bevölkerungsgruppen }\end{array}$ \\
\hline Ökonomische Ziele & $\begin{array}{l}\text { - Sicherung und Schaffung regionaler Arbeitsplätze in innovativen, } \\
\text { umweltorientierten Betrieben } \\
\text { - Erhaltung und Verbesserung der finanziellen öfentlichen Handlungsspielräume }\end{array}$ \\
\hline
\end{tabular}


Folgende Regionen nehmen am Ideen- und Realisierungswettbewerb "Regionen der Zukunft" teil:

\author{
Flensburg/Schleswig \\ Eider-Treene-Sorge \\ Mecklenburgische Seenplatte \\ Metropolregion Hamburg \\ Berlin-Brandenburg/Prignitz-Oberhavel \\ Aller-Leinetal \\ Grofraum Brounschweig \\ Havelland-Fläming \\ Expo-Region Hannover \\ EUREGIO (einschlieflich EUREGI0-Forum) \\ Südniedersachsen \\ Industrielles Gartenreich Dessau- \\ Bitterfeld-Wittenberg \\ Modellregion Märkischer Kreis \\ Nordthüringen
}

Zukunftsregion Südraum Leipzig

Rhön

Wirtschaftsregion Chemnitz-Zwickau

Frankfurt-Rhein-Main-Wiesbaden

Storkenburg

Cham

Deutsch-Französischer Kooperationsraum PAMINA

Stuttgart

Teilraum Deggendorf/Plattling

Freiburg-Breisgau

Hochschwarzwald-Emmendingen

Kooperationsraum Bodensee-Oberschwaben

München
Von daher bedarf sie verstärkt der Ergänzung und Flankierung, um ihre Lenkungspotentiale besser entfalten zu können.

Die eine Richtung kann - wie es die vom Bundesministerium für Raumordnung, Bauwesen und Städtebau eingesetzte ,Kommission Zukunft Stadt 2000" zugespitzt formuliert hat - mit der Forderung „Preise statt Pläne“ umrissen werden. Denn es herrscht weitgehend Einigkeit, daß

\section{"Regionale Good Practices" - Neves IöW-Projekt}

Seit dem I. September führt das löW im Auftrog der IFOK GmbH, Bensheim, die Expertise "Regionale Good Proctices einer Nachhaltigen Raum- und Siedlungsentwicklung" durch. Im Rahmen der Expertise wird eine Daterbank oufgebout, die alle notionalen Projekte, die nachhalige Entwicklung in einen regionalen Kontext stellen, erfassen soll. Auf der Basis dieser Informationen und zusätzlicher Recherchen werden besonders erfolgreiche und originelle Projekte im Rahmen eines Handbuches "Good Practices" abschliefend dar gestellt. Die Projektergebnisse dienen zur weiteren methodischen und inhallitichen Konkretisierung des Wettbewerbs "Regionen der Zukunft", der von der Bundesanstalt für Bouwesen und Raumordnung ausgeschrieben wurde.

Regionale Projekte, die in die Datenbank aufgenommen werden wollen, können sich direkt an dos löWRegionalbüro in Wuppertal wenden.

Kontakt: Rainer Lucas, IÖW-Regionalbüro NRW, Völklinger Str. 9, 42285 Wuppertal.

E-Mail: moilbox@ioew.w.eunet.de der Staat über die Beeinflussung der Preise - die zentralen Stellschrauben in Marktwirtschaften -ökologische Leitplanken installieren soll, um das Verhalten der wirtschaftlichen Akteure mit den Erfordernissen einer Nachhaltigen Entwicklung in Einklang zu bringen.

Die andere Richtung wurde oben schon unter dem Stichwort „Projekt- und Prozeßorientierung“ angeschrieben. Damit wird der Weg umfassender Planungsansätze verlassen und ein pragmatischer - dezentraler und umsetzungsbezogener - Kurs eingeschlagen. Sich weiter ausdifferenzierende räumliche Strukturen erfordern eine stärkere Orientierung an den jeweilig unterschiedlichen Bedingungen der einzelnen Städte und Regionen. Die bundesstaatliche Politik formuliert Leitvorstellungen und gibt Impulse, die von den lokalen und regionalen Akteuren aufgegriffen und umgesetzt werden können. Den Akteuren wächst so mehr Eigenständigkeit für ihre Entwicklung zu - die übergeordneten föderalen Ebenen werden zu Moderatoren dieses Prozesses.

\section{Dialog und Kooperation}

Getragen werden müssen diese Prozesse aber von den Gemeinden und Regionen selbst. Voraussetzung hierfür ist Dialog nach innen und Kooperation nach außen. Die aktive Einbeziehung von Bürgerinnen und Bürgern - oder umfassender gesagt: aller gesellschaftlichen Interessengruppen - in den Realisierungsprozeß einer Nachhaltigen Entwicklung gewinnt seine Bedeutung aus der langiährigen Erfahrung heraus, daß die Umsetzung entsprechender Konzepte nur im Dialog mit allen beteiligten Akteuren gelingen kann. Die Kooperation nach außen schafft die Voraussetzungen, auf einer adäquaten räumlichen Maßstabsebene die anstehenden Probleme zu lösen. Die Teilnehmer im Wettbewerb ,Regionen der Zukunft" haben entsprechende Strukturen geschaffen oder geplant. Aus der Einsicht, daß hierdurch eine bessere Lösung der anstehenden Probleme ermöglicht wird, haben sie sich bereit erklärt, mit ihren Bürgerinnen und Bürgern in einen Dialog zu treten, und mit anderen Gebietskörperschaften, relevanten Institutionen und Akteuren zu kooperieren.

Dabei wird ihnen durch die Vernetzung im Rahmen des Wettbewerbs Hilfestellung gegeben, u.a. das Lernen von den Projekten anderer Regionen und der Meinungs- und Erfahrungsaustausch in wettbewerbsbegleitenden Veranstaltungen. Die fachliche Begleitung durch das Bundesamt für Bauwesen und Raumordnung bietet eine Unterstiitzung, indem die Planungs- und Entscheidungsgrundlagen der jeweiligen Projekte, mit denen die regionalen Akteure eine nachhaltige Entwicklung anstreben, erweitert oder besser abgesichert werden können. Denn das ehrgeizige Ziel steht fest: die Prämierung und Präsentation besonderer Leistungen im Rahmen des Wettbewerbs auf der Weltkonferenz URBAN 21 im Juli 2000 in Berlin.

\section{Anmerkungen}

(1) Im Internet zu finden unter hitt://www.zukunftsregionen.de (2) Am 1. Januar 1998 sind die Bundesforschungsanstalt für Landeskunde und Raumordnung (BfLR) und die Bundesbaudirektion (BBD) zum Bundesamt für Bauwesen und Raumordnung (BBR) zusammengeführt worden.

\section{Die Autorlnnen}

Eckhard Bergmann und Drigitie Adam sind wissenschaftliche Mitarbeiterlmnen des Bundesamtes für Bauwesen und Raumordnung, Bonn. Sie geben in diesem Beitrag ihre persönliche Meinung wieder. Kontakt: BBR, Am Michaelshof 8, 53177 Bonn, Tel. 0228/ 826-340 (Bergmann), -325 (Adam)

Wollen Sie einen Überblick über die bisherigen Inhalte des Informationsdienstes "Ökologisches Wirtschaften"?

Dann wählen Sie sich einfach ein unter http://www.umwelt.de/magazin/ oekowirt

Unter dieser Adresse können Sie zugleich auch bestellen. 
(c) 20I0 Authors; licensee IÖW and oekom verlag. This is an article distributed under the terms of the Creative Commons Attribution Non-Commercial No Derivates License (http://creativecommons.org/licenses/by-nc-nd/3.o/), which permits unrestricted use, distribution, and reproduction in any medium, provided the original work is properly cited. 